\title{
PENGARUH KUALITAS KEHIDUPAN KERJA DAN KETERLIBATAN KERJA TERHADAP KEPUASAN KERJA GURU SMP NEGERI SE-KECAMATAN TELUKNAGA KABUPATEN TANGERANG
}

\author{
Neneng Riyana Novita*
}

\begin{abstract}
The research was conducted to all teachers of junior higt school districts teluknaga regency of Tangerang. By using a survey method with path analysis applied in testing hypothesis the number 113 teachers as sample was selected by using Slovin formula. Based on the results of data analysis in this research it is concluded: (1) the quality of work life have positive direct effect to job satisfaction; (2) the job involvement have positive direct effect to job satisfaction; (3) the quality of work life have positive direct effect to job involvement. The job satisfaction can be improv through improvement of quality of work life and job involvement
\end{abstract}

Keywords: Job satisfaction, quality of work life and job involvement.

\section{PENDAHULUAN}

Lembaga sekolah hingga saat ini masih menjadi icon dalam menciptakan sumberdaya manusia yang handal dan mampu bersaing dalam skala nasional maupun skala internasional, selain itu lembaga sekolah juga memiliki aset yang tak kalah pentingnya dalam menunjangn terciptanya sumberdaya manusia yang disebutkan tadi yakni guru.

Guru merupakan ujung tombak dalam peningkatan mutu pendidikan, oleh karena itu, guru harus mendapatkan perhatian yang lebih baik dari segi kesejahteraan maupun hal-hal yang lain yang akan menunjang pelaksanaan tugas fungsinya. Perhatian tersebut diharapkan agar guru merasa senang dengan pekerjaannhya, puas dalam menjalankan tugasnya serta selalu melibatkan diri dalam segala kegiatan yang diadakan sekolah.

Pimpinan sekolah kiranya memiliki strategi dalam menyelesaikan persoalan internal lembaga misalnya mengatasi ketidakpuasan kerja guru, kurangnya keinginan guru untuk berpartisipasi dalam segala bentuk kegiatan sekolah dan tidak perduli dengan program sekolah yang telah di cantumkan dalam visi sekolah serta dijabarkan dalam misi sekolah.

Banyaknya guru yang merasa tidak puas dalam bekerja mengakibatkan rendahnya kinerja guru yang bersangkutan sehingga apa yang telah di rencanakan sebelumnya akan sulit untuk diimplementasikan mengingat karena banyaknya guru yang tidak perduli dengan tugas-tugas yang berikan.

Mengingat hal fenomena tersebut, maka kepala sekolah harus mengambil langkah untuk membangkitkan semangat para guru yang selama ini memiliki kinerja yang

* Asisten Dosen Universitas Muhammadiyah Makassar 
rendah, kepala sekolah harus dengan cepat mengambil keputusan demi mencegah hal-hal yang lebih besar yang kemungkinan terjadi yakni terjadinya intense turnover atau bahkan turnover " Maka dari itu peneliti ingin mengkaji secara ilmiah apakah Kualitas Kehidupan kerja berpengaruh terhadap kepuasan kerja guru SMP Negeri se-Kecamatan Teluknaga Kabupaten Tengerang.

Menurut McShane dan Von Glinow (2008:108), “job satisfaction is a person's evaluation of his or her job and work context". Kepuasan kerja adalah penilaian seseorang dalam pekerjaan dan hubungan kerjanya. Lalu menurut Colquitt dkk (2011:158), "job satisfaction is defined as a pleasure emotional state resulting from the appraisal of one's job experiences". Kepuasan kerja didefinisikan sebagai keadaan emosional yang menyenangkan yang dihasilkan dari penilaian dari pekerjaan atau pengalaman kerja.

Menurut Mathis dan Jackson (2012:25), "job satisfaction is a positive emotional state resulting from evaluating one's job experiences". Kepuasan kerja adalah keadaan emosi yang positif yang dihasilkan dari evaluasi pengalaman kerja seseorang. Lalu menurut Locke (2001:26), "job satisfaction as 'a pleasurable or positive emotional state resulting from the appraisal of one's job or job experiences". Kepuasan kerja sebagai keadaan emosional yang menyenangkan atau positif yang dihasilkan dari penilaian dari seseorang pekerjaan atau pengalaman kerja'.

Sedangkan menurut Gibson dkk (2006:373), "job satisfaction is an individual's expression of personal well-being-associated with doing the job assigned". Kepuasan kerja adalah ekspresi individu terhadap kesejahteraan personal secara umum dengan tugas pekerjaannya. Lalu menurut Mullins (2010:282), "job satisfaction is an attitude or internal state that is associated with, for example, a personal feeling of achievement either quantitative or qualitative". Kepuasan kerja adalah sikap atau keadaan internal yang berhubungan dengan, misalnya, perasaan pribadi prestasi baik kuantitatif atau kualitatif.

Menurut Angelo Kinicki, Brian K. Williams (2010:350) mengatakan bahwa, "job satisfaction is the extent to which you feel positive or negative about various aspects of your work. Their overall satisfaction depends on how they feel about several components, such as work, pay, promotions, coworkers and supervision. Kepuasan kerja adalah sejauh mana merasa positif atau negatif tentang berbagai aspek dari pekerjaannya. Kepuasan mereka secara keseluruhan tergantung pada bagaimana perasaan mereka tentang beberapa komponen, seperti pekerjaan itu sendiri, gaji, promosi, rekan kerja dan pengawasan.

Menurut Madhurima Lall dan Sakina Qasim Zaidi (2012:157), "an employees would be happy with their jobs and would love to work for an organization motive, if they get fair rewards in exchange of their services". Karyawan akan senang dengan pekerjaan mereka dan akan senang untuk bekerja untuk sebuah motif organisasi, jika mereka mendapatkan imbalan yang adil dalam pertukaran layanan mereka.

Gibson et al (2003:353), "a philosophy of management that enhances the dignity of all workers; introduces changes in an organization's culture; and improve the physical and emotional well-being of employees". Definisi ini menunjukkan bahwa kualitas 
kehidupan kerja merupakan filosofi manajemen yang berusaha meningkatkan martabat karyawan, memperkenalkan perubahan budaya, dan menyediakan peluang untuk tumbuh dan berkembang. Sementara itu John Bernardin dan Joyce Russel (1993:520) berpandangan bahwa, "quality of work life is the degree to which individuals are able to satisfy their important personal needs while employed by the firm."

Menurut Schemerhom, Hunt dan Osborn (2005:38) bahwa kualitas kehidupan kerja merupakan, "the overall quality of human experiences in the workplace". Pengertian ini mengandung makna yang luas bahwa kualitas kehidupan kerja mencakup keseluruhan pengalaman di tempat kerja. Ini berarti meliputi aktivitas kerja, relasi sosial antar karyawan, bahkan aspek-aspek yang terdapat dalam lingkungan kerja, seperti kompensasi, rekan kerja, dukungan manajemen, supervisi, tanggung jawab, dan lain-lain.

Kualitas kehidupan kerja adalah suatu pengalaman setiap individu untuk untuk terus berkembang dalam memenuhi kebutuhan pribadinya serta perasaan senang dalam menjalankan tugas fungsinya dalam organisasi yang mereka tempati.

Ivancevich, Konopaske, dan Matteson (2008:139) mengartikan, "quality of work life is widely used to refer to "a philosophy of management that enhances to the dignity of all worker; introduces changes in an organization's culture; and improves the physical and emotional will -being of employees. Penjelasan tesebut dapat diartikan bahwa kualitas kehidupan kerja secara luas digunakan untuk merujuk kepada "filosofi manajemen yang meningkatkan martabat semua pekerja; memperkenalkan perubahan dalam budaya organisasi; dan meningkatkan kemauan fisik dan emosional-menjadi karyawan.

Sementara itu, Luthan (2008:355) memberikan definisi yang lebih spesifik dan operasional dengan mengatakan bahwa, "QWL is more concerned with the overall work climate or culture. QWL may be described as a concern about the impact of work on people and organizational effectiveness combined with an emphises on participation in problem solving and decision making. Definisi tersebut menyatakan bahwa kualitas kehidupan kerja merupakan keseluruhan iklim kerja atau budaya dan juga menekankan perhatian pada penggambaran pekerjaan terhadap orang dan efekvitivas organisasi yang dikombinasikan dengan sebuah penekanan pada partisipasi dalam penyelesaian masalah dan pengambilan keputusan.

Selanjutnya menurut Donald D. White \& David A. Badnar (1991:483-484) mengatakan tentang kriteria dari kualitas kehidupan kerja, sebagai berikut, "perhaps the most comprehensive and well-known definition of QWL suggests eight mayor criteria that characterize a high quality of work life. Each criterion is described briefly below: 1) Adequate and fair compensation; 2) Safe and healthy environment; 3) Immediate opportunity to use and develop human capacities; 4) Future opportunity for continued growth and security; 5) Social integration in ihe work organization; 6) Constitutionalism in the work organization; 1) Work and the total life space; 8) The social relevance of work life

Definisi yang paling komprehensif dan dikenal dari QWL menunjukkan delapan kriteria yang mencirikan kualitas kehidupan kerja yang tinggi. Setiap kriteria dijelaskan secara singkat di bawah ini: 1) kompensasi yang memadai dan 
adil; 2) lingkungan kerja yang aman dan sehat; 3) kesempatan menggunakan dan mengembangkan kapasitas pegawai; 4) kesempatan masa depan untuk pertumbuhan dan keamanan berkelanjutan; 5) integrasi sosial dalam organisasi kerja; 6) konstitusional dalam organisasi kerja, 7) kerja dan ruang hidup keseluruhan, 8) Relevansi sosial kehidupan kerja.

Luthans (2008:356) juga menjelaskan bahwa tujuan dari program kualitas kehidupan kerja adalah "to change and improve the work climate so that the interface of people, technology, and the organization makes for a more favorable work experience and desired outcomes". Hal ini mengisyaratkan bahwa tujuan kualitas kehidupan kerja adalah mengubah dan meningkatkan iklim kerja sehingga penghubung dari orang, teknologi dan organisasi tercipta untuk pengalaman kerja yang lebih menyenangkan dan memberikan hasil sesuai yang dikehendaki.

Selanjutnya menurut Davis \& Newstrom (1995:332-333) bahwa, "QWL produces a more humanized work enviroment. It attempts to serve the higher-order needs of workers as well as their more basic needs. It seeks to employ the higher skills of workers and to provide and environment that encourages them to improve their skills. The idea is that workers are human resources that are to be developed rather than simply used. Further, the work should not have excessively negative conditions. It should not put workers under undue stress. It should not damage or degrade their humanness. It should not be threatening or unduly dangerous. Finally, it should contribute to, or at least ieave unimpaired, workers' abilities to perform in other life roles, such as citizen, spouse, and parent. This is, work should contribute to general social advancement".

QWL menghasilkan lingkungan kerja yang lebih manusiawi, la mencoba untuk melayani kebutuhan tingkat tinggi dari para pegawai serta kebutuhan mereka yang lebih mendasar. Ini berusaha untuk menggunakan keterampilan pegawai yang lebih tinggi dan untuk menyediakan lingkungan yang mendorong mereka untuk meningkatkan keterampilan mereka. Idenya adalah bahwa pekerja adalah sumber daya manusia yang akan dikembangkan bukan hanya digunakan. Selanjutnya, pekerjaan tidak harus memiliki kondisi negative yang berlebihan. Ini tidak perlu menempatkan pekerja di bawah tekanan yang tidak semestinya. Seharusnya tidak merusak atau menurunkan kemanusiaan mereka. Seharusnya tidak mengancam atau terlalu berbahaya. Akhirnya, harus berkontribusi, atau setidaknya meninggalkan utuh, kemampuan pekerja untuk melakukan dalam peran kehidupan lainnya, seperti warga negara, pasangan, dan orang tua. Ini, kerja harus memberikan kontribusi untuk kemajuan sosial umum.

Menurut Noe et. al. (2014:321), "job involvement is the degree to which people identify themselves with their jobs". Keterlibatan kerja adalah sejauh mana seseorang mengidentifikasi diri dengan pekerjaan mereka. Selanjutnya Rae Andre (2008:48) menjelaskan bahwa,"job involvement is the belief that there is a relationship between an individual's performance in a job and his or her own self-worth". Keterlibatan kerja adalah keyakinan bahwa adanya hubungan antara kinerja individu dalam pekerjaan dan harga dirinya sendiri 
Anggota sebagai roda organisasi harus diperhatikan perkembangannya agar mendapatkan hasil yang optimal. Salah satu cara untuk meningkatkan kualitas kerja anggota adalah dengan keterlibatan kerja, karena keterlibatan kerja dalam setiap organisasi akan memberikan kepuasan kerja dan anggota akan menjadi bertanggung jawab terhadap pekerjaannya dan akan berdampak pada kinerja. Menurut Chelladurai (2006:296), "Job involvement as the extent to which an individual identifies psychologically with his/her job". Keterlibatan kerja sebagai sejauh mana seorang individu mengidentifikasi secara psikologis dengan pekerjaannya.

Menurut Schermerhorn, et al, (2011:72), "Job involvement is the extent to which an individual is dedicated to a job. Someone with high job involvement psychologically identifies with her or his job, and, for example, would be expected to work beyond expectations to complate a special project. Keterlibatan kerja adalah sejauh mana seorang individu didedikasikan untuk pekerjaan. Seseorang dengan keterlibatan kerja yang tinggi mengidentifikasi secara psikologi dengan atau pekerjaannya, dan misalnya akan diharapkan untuk bekerja melampaui harapan untuk menyelesaikan sebuah proyek khusus.

Sedangkan menurut Srivastana (2005:95) menjelaskan keterlibatan kerja ialah, "the job involved person is highly motivated and feels a sense of pride in his work. Thus, job involvement can be considered as an important measure of organisational effectiveness that may be at least in part, influenced by job staisfaction. Pekerjaan melibatkan seseorang yang memiliki motivasi tinggi dan merasa bangga dalam pekerjaannya. Dengan demikian, keterlibatan kerja dapat dianggap sebagai ukuran penting dari efektivitas organisasi yang mungkin sebagian dipengaruhi oleh kepuasan kerja.

Menurut Kondalkar (2007:87), "job involvement refers to the degree to which a person identifies himself (psychologically) with his job, actively participates and considers his perceived performance level important to self-worth. High level of involvement indicates that the individual cares for his job, that has an impact on high productivity. Higher the job satisfaction, lower will be absenteeism and employee turnover. Keterlibatan kerja mengacu pada sejauh mana seseorang mengidentifikasi dirinya (psikologis) dengan pekerjaannya, aktif berpartisipasi dan menganggap tingkat penampilannya dianggap penting untuk harga diri. Tingkat keterlibatan yang tinggi menunjukkan bahwa individu yang peduli untuk pekerjaannya, yang memiliki dampak pada produktivitas yang tinggi. Lebih tinggi kepuasan kerja, lebih rendah akan absensi dan perputaran karyawan.

Sedangkan menurut Robbins (2013:74), menjelaskan bahwa, "the degree to which people identify psychologically with their job and consider their perceived performance level important to self-worth. Employees with a high level of job involvement strongly identify with and really care about the kind of work they do. Another closely related concept is psychological empowerment, employees' beliefs in the degree to which they influence their work environment, their competence, the meaningfulness of their job, and their perceived autonomy.

Tingkatan seseorang dalam mengidentifikasi secara psikologis dengan pekerjaan mereka dan mempertimbangkan tingkat kinerja mereka dianggap penting 
untuk harga diri. Karyawan dengan tingkat tinggi keterlibatan kerja sangat mengidentifikasi dengan dan benar-benar peduli tentang jenis pekerjaan yang mereka lakukan. Konsep lain yang terkait erat adalah pemberdayaan psikologis, kepercayaan karyawan di tingkat mana mereka mempengaruhi lingkungan mereka kerja, kompetensi mereka, kebermaknaan pekerjaan mereka, dan otonomi mereka dirasakan.

Senada dengan DuBrin (2012:236) menjelaskn bahwa, "job involvement is the degree to which individuals identify psychologically with their work. It also refers to the importance of work to a person's total self-image. If an insurance claims examiner regards his job as a major part of his identity, he experiences high job involvement". Keterlibatan kerja adalah sejauh mana individu mengidentifikasi secara psikologis dengan pekerjaan mereka. Hal ini juga mengacu pada pentingnya kerja terhadap total citra diri seseorang. Jika pemeriksa klaim asuransi menganggap pekerjaannya sebagai bagian utama dari identitasnya, ia mengalami keterlibatan kerja yang tinggi.

Lalu Tomas (2008:07) juga menjelaskan bahwa, "job involvement is the degree to which employees engage (immerge) themselves in their jobs, invest time and energy in them and view work as a central part of their overall lives. Keterlibatan kerja adalah sejauh mana karyawan terlibat (tenggelam) diri mereka dalam pekerjaan mereka , menginvestasikan waktu dan energi di dalamnya dan melihat pekerjaan sebagai bagian sentral dari kehidupan mereka secara keseluruhan.

\section{METODE}

Penelitian ini dilaksanakan di SMP Negeri se-Kecamatan Teluknaga Kabupaten Tangerang dilaksanakan selama 3 (tiga) bulan. Metode yang digunakan dalam penelitian ini adalah survey dengan menggunakan teknik kausal. Populasi adalah guru SMP Negeri se-Kecamatan Teluknaga Kabupaten Tangerang yang berjumlah 117 pegawai dengan jumlah sampel sebanyak 113 guru. Data yang dikumpulkan dalam penelitian dijaring melalui kuesioner yang berupa skala penilaian (rating scale) dengan sebaran skor antara 1 sampai dengan 5 .

Setelah dilakukan analisis deskriptif dilanjutkan dengan uji persyaratan analisis berupa uji normalitas, uji linearitas data dan keberartian regresi, dilakukan uji hipotesis dengan menggunakan teknik analisis jalur (path analysis).

\section{HASIL DAN PEMBAHASAN}

\section{Pengaruh Kualitas kehidupan kerja terhadap Kepuasan kerja}

Hasil penelitan ini menunjukkan bahwa kualitas kehidupan kerja memberikan pengaruh positif secara langsung terhadap kepuasan kerja. Besarnya pengaruh tersebut ditunjukkan oleh koefisien korelasi 0,646 dan koefisien jalur 0,481 . Hal ini menujukkan bahwa kualitas kehidupan kerja dapat meningkatkan kepuasan kerja guru.

Hasil penelitian ini sejalan dengan pendapat Luis (2012:20) bahwa, " $a$ growing number of companies recognize that employees are more likely to choose a firm and stay there if they believe that it offers a high quality of work life. A high quality of work life is 
related to job satisfaction, which, in turn, is a strong predictor of absenteeism and turnover". Semakin banyak lembaga menyadari bahwa guru lebih cenderung untuk memilih sebuah lembaga dan tinggal di sana jika guru percaya bahwa itu menawarkan kualitas kehidupan kerja yang tinggi. Sebuah kualitas kehidupan kerja yang tinggi adalah terkait dengan kepuasan kerja, yang, pada gilirannya, adalah prediktor kuat dari absensi dan turnover.

Lebih lanjut luis (2005:703) menjelaskan bahwa, "some of the major factors which have a particular influence on job satisfaction include: Information communications technology; Stress at work; Work organisation and individual job design; Comprehensive model of job enrichment; Broader organisational approaches; Quality of working life; Work/life balance; Involvement, Empowerment and groups; Flexible working arrangements; Quality circles".

Beberapa faktor utama yang memiliki pengaruh tertentu pada kepuasan kerja meliputi: Informasi teknologi komunikasi; Stres di tempat kerja; organisasi kerja dan desain pekerjaan individu; model komprehensif dari pengayaan pekerjaan; pendekatan organisasi yang lebih luas; Kualitas kehidupan kerja; keseimbangan kerja / hidup; Keterlibatan, Pemberdayaan dan kelompok; pengaturan kerja yang fleksibel; lingkaran kualitas.

\section{Pengaruh Keterlibatan kerja terhadap Kepuasan kerja}

Hasil penelitan ini menunjukkan bahwa keterlibatan kerja memberikan pengaruh positif secara langsung terhadap kepuasan kerja. Besarnya pengaruh tersebut ditunjukkan oleh koefisien korelasi 0,587 dan koefisien jalur 0,377.

Hasil penelitian ini sejalan dengan pendapat Stephen robbins (2013:74) bahwa, "related to job satisfaction is job involvement, which measures the degree to which people identify psychologically with their job and consider their perceived performance level important to self-worth. Employees with a high level of job involvement strongly identify with and really care about the kind of work they do. Another closely related concept is psychological empowerment employees' beliefs in the degree to which they influence their work environment, their competence, the meaningfulness of their job, and their perceived autonomy".

Terkait dengan kepuasan kerja adalah keterlibatan kerja, yang mengukur sejauh mana guru mengidentifikasi secara psikologis dengan pekerjaannya dan mempertimbangkan tingkat kinerja guru dianggap penting untuk harga diri. Guru dengan tingkat tinggi keterlibatan kerja sangat mengidentifikasi dengan dan benarbenar peduli tentang jenis pekerjaan yang guru lakukan. Konsep lain yang terkait erat adalah keyakinan psikologis pemberdayaan guru di tingkat mana guru mempengaruhi lingkungan kerjanya, kompetensi guru, kebermaknaan pekerjaan guru, dan otonomi yang guru rasakan.

Lebih lanjut, Robert Kreitner dan Angelo Kinicki (2006:370) menyatakan hal yang senda juga dalam bukunya yakni, "job involvement was positively attracted with job satisfaction, organizational commitment, and intrinsic motivation, and negatively related to intentions to quit. The three key managerial implications associated with these results, 
first, managerial attempts to improve any one of the three key work attitudes discussed in this section-job satisfaction. organizational commitment, and job involvement-are likely to positively affect the other two work attitudes. ${ }^{38}$

Keterlibatan kerja yang positif berpengaruh dengan kepuasan kerja, komitmen organisasi, dan motivasi intrinsik, dan berpengaruh negatif dengan niat untuk berhenti. Tiga implikasi kunci manajerial yang terkait dengan hasil ini. Pertama, upaya manajerial untuk meningkatkan salah satu dari tiga sikap

\section{Pengaruh Kualitas kehidupan kerja terhadap Keterlibatan kerja}

Hasil penelitan ini menunjukkan bahwa kualitas kehidupan kerja memberikan pengaruh positif secara langsung terhadap keterlibatan kerja. Besarnya pengaruh tersebut ditunjukkan oleh koefisien korelasi 0,436 dan koefisien jalur 0,436 .

Hasil penelitian ini sejalan dengan pendapat Gibson (2006:370) bahwa, "in some organizations, QWL programs are intended to increase employee trust, productivity, involvement, retention, and problem solving so as to increase both worker satisfaction and organizational effectiveness. Thus, the concept and application of QWL are broad and involve more than jobs, but the jobs that people do are important sources of satisfaction.

Dalam beberapa organisasi, program QWL dimaksudkan untuk meningkatkan kepercayaan guru, produktivitas, keterlibatan, retensi, dan pemecahan masalah sehingga dapat meningkatkan baik kepuasan pekerja dan efektivitas organisasi.

Menurut James L. Gibson et. a!. (2006:37) dalam bukunya menyatakan bahwa, "QWL programs are intended to increase employee trust, productivity, involvement, retention, and problem solving so as to increase both worker satisfaction and organizational effectiveness".

Program QWL dimaksudkan untuk meningkatkan kepercayaan guru, produktivitas, keterlibatan, retensi, dan pemecahan masalah sehingga dapat meningkatkan baik kepuasan pekerja dan efektivitas organisasi. Selanjutnya

Menurut Jerald Greenberg (2011:609) dalam bukunya menyatakan bahwa, "as more people demand satisfying and personally fulfilling places to work, OD practitioners have attempted to create work situations that enhance employees' motivation, satisfaction, and commitment-factors that may contribute to high levels of organizational performance. Such efforts are known collectively as quality of work life (QWL).

Semakin banyak guru menuntut secara pribadi memuaskan dan memenuhi tempat untuk bekerja, praktisi OD telah berusaha untuk menciptakan situasi kerja yang meningkatkan motivasi guru, kepuasan, dan komitmen-faktor yang dapat berkontribusi terhadap tingginya tingkat kinerja organisasi. Upaya tersebut dikenal secara kolektif sebagai QWL.

Selanjutnya menurut John M. Ivanchevich (1999:229) menyatakan dalam bukunya bahwa, "QWL are intended to increase employees' trust, involvement, and problem solving so as to increase both workers satisfaction and organizational effectiveness". QWL dimaksudkan untuk meningkatkan kepercayaan guru, keterlibatan, dan 
pemecahan masalah sehingga dapat meningkatkan kepuasan baik pekerja dan efektivitas organisasi.

William B. Werther, JR. \&Keith Davis (1999:463) menyatakan dalam bukunya bahwa, "however; effective QWL can supplement other personnel actions and provide improved employee motivation, satisfaction, and productivity. QWL is most commonly improved through employee involvement'. Namun, efektif QWL dapat melengkapi tindakan guru lainnya dan memberikan peningkatan motivasi guru, kepuasan, dan produktivitas. QWL ini paling sering ditingkatkan melalui keterlibatan guru.

Pendekatan-pendekatan dan upaya-upaya untuk menghadirkan kualitas-kualitas dalam bekerja yang dilakukan oleh organsiasi dalam hubungannya dengan guru dapat dipandang sebagai tindakan yang penuh kebijkasanaan dan mencerminkan

\section{PENUTUP}

Kesimpulan: (1) kualitas kehidupan kerja berpengaruh langsung positif terhadap kepuasan kerja guru. Artinya, semakin tinggi kualitas kehidupan kerja guru maka akan semakin tinggi kepuasan kerja guru SMP Negeri se-Kecamatan Teluknaga Kabupaten Tangerang. (2) keterlibatan kerja berpengaruh langsung positif terhadap kepuasan kerja guru. Artinya, semakin tinggi keterlibatan kerja guru maka akan mengakibatkan peningkatan kepuasan kerja guru SMP Negeri se-Kecamatan Teluknaga Kabupaten Tangerang. (3) kualitas kehidupan kerja berpengaruh langsung positif terhadap keterlibatan kerja. Artinya, semakin tinggi kualitas kehidupan kerja guru akan mengakibatkan peningkatan keterlibatan kerja guru SMP Negeri se-Kecamatan Teluknaga Kabupaten Tangerang.

Saran: saran - saran untuk guru. diharapkan dapat meningkatkan kualitas kehidupan kerja agar dapat meningkatkan kepuasan kerja adalah: 1) ikhlas dalam melaksanakan tugas dan fungsinya, 2) Senantiasa bersikap santun terhadap sesama maupun pimpinan. 3) mampu mengotrol diri dalam mengatasi permasalahan yang ada, menjaga stabilitas emosional dalam menjaga kestabilan dan kenyamanan.

Kedua, saran untuk guru terkait dengan keterlibatan kerja agar meningkatkan kepuasan kerja adalah: 1) pegawai harus mengedepankan kepentingan lembaga, 2) aktif dalam menyukseskan program sekolah, 3) memberikan keyakinan kepada diri bahwa melaksanakan tugas adalah kebutuhan bukan kewajiban.

\section{DAFTAR RUJUKAN}

Andre, Rae. Organizational Behavior: An Introduction to Your Live in Organizations USA: Pearson Prentice Hall, 2008.

Ayman Adham., Employee Involvement and its Impact on job Satisfaction and Organisational Commitment. Saudi Arabia: International Journal of Sciences Basic and Applied Research., 2011.

Chelladurai, P., Human Resosurce Management in Sport and Recreation. USA: Chelladurai., 2006. 
Colquitt, et al., Organizational Bahavior. New York: McGraw-Hill., 2009.

DuBrin, Andrew J, Essential Of Management 9th Edition. USA: South-Western., 2012.

Gibson, James L, et al., Organizational: Behavior, Structure, Processes. New York: McGraw-Hill., 2006.

Greenberg, Jerald. Behavior in Organizations Tenth Edition. United Kingdom: Pearson, 2011.

Ivancevich, Konopaske, Matteson, Organizational Behavior and Management, Eight Edition. New York: Mc Graw-Hill, 2008.

Kinicki, Angelo, Brian K. Wiliams, Management a Practical Introduction. New York: McGraw-Hill, 2011.

Luis R. Gómez-Mejía, David B. Balkin, Robert L. Cardy., Managing Human Resources 7th Ed. USA : Pearson Education, Inc., Prentice Hall., 2012.

Luthans, Fred. Organizational Behavior, 11 th Edition. Boston: McGraw-Hill, 2008.

Madhurima Lall and Sakina Qasim Zaidi., Human Resource Management. New Delhi: Excel Books Private Limited., 2012.

Mathis, Robert L. and John H. Jackson., Human Resource Management 13th Edition., USA: South-Western Cengage Learning., 2011.

McShane, Steven L. and Mary Ann Von Glinow., Organizational Behavior 4th: Emerging Realities For The Workplace Revolution., New York: McGraw-Hill., 2008.

Mullins, Laurie J. Management and Organisational Behaviour 9th Edition., Pearson: Prentice Hall., 2010.

Noe et. al., Fundamental of Human Resource Management Fifth Edition. New York: McGraw-Hill, 2014.

Robbins, Stephen P.and Timothy A. Judge., Organizational Behavior 15th Edition., New Jersey: Pearson Education Prentice Hall., 2013.

Schermerhorn, et al., Organizational Behavior., Asia: John Wiley \& Sons Inc., 2011.

Schermerhorn, John R. Jr, James G, Hunt and Richard N. Osbon, Organizational Behavior. New Jersey: John Wiley \& Sons Inc, 2005.

Sopan. Seminar Nasional yang dilaksanakan di UNJ di Gedung Dewi Sartika.15/11/2015.

Srivastana, S. K., Organizational Behavior and Management., New Delhi: Sarup and Sons., 2005.

Tomas, Babu., High Performing Organisations., New Delhi: McGraw-Hill., 2008.

V. G. Kondalkar., Organizational Behavior., New Delhi: New Age International., 2007. 